\title{
GLIMPSE: Using Social Media to Identify the Barriers Facing Farmers' Quest to Feed the World
}

\author{
Aidan J. Connolly, Luiz R. Sodre, Alexa D. Potocki \\ Alltech, Inc., Nicholasville, KY, USA \\ Email: aconnolly@alltech.com, luizrobertosodre@gmail.com, apotocki@alltech.com
}

How to cite this paper: Connolly, A.J., Sodre, L.R. and Potocki, A.D. (2016) GLIMPSE: Using Social Media to Identify the Barriers Facing Farmers' Quest to Feed the World. Social Networking, 5, 118-127. http://dx.doi.org/10.4236/sn.2016.54012

Received: September 28, 2016

Accepted: October 28, 2016

Published: October 31, 2016

Copyright $\odot 2016$ by authors and Scientific Research Publishing Inc. This work is licensed under the Creative Commons Attribution International License (CC BY 4.0).

http://creativecommons.org/licenses/by/4.0/

\begin{abstract}
The ubiquitous nature of social media in today's world offers unparalleled insights into human thinking. When people write Facebook posts, blogs, Tweet, Instagram and WeChat they allow their real feelings and reflections to be exhibited, unvarnished and unfiltered. From this perspective the use of data analytical tools such as Wordle word association mapping and other tools can truly show through frequency of word used, word connections and consumer insights. The example of farming and food production is instructive. Five years ago a new acronym GLIMPSE in IFAMR was proposed to summarize the barriers faced by agriculture in its quest to feed the world. This was based on a Delphi analysis of 25 expert interviews. In order to confirm GLIMPSE, a larger research effort interviewed 57 experts, conducted an online survey with almost 600 experts and for the first time ever in this sector algorithms were applied to over 1.3 million qualified social media postings on the internet referring to the challenge of feeding a growing world population. This allowed the comparison to confirm the factors that most clearly depict the general public's concerns with respect to food production and agriculture. The value for policy makers is clear. While international policy makers, governments, non-governmental organizations (NGOs), charities, industry organizations, integrated food companies and farmers often struggle to explain to the general population the challenges of increasing food production of both large and small scale farming the social media analysis is unique and original in its ability to confirm the GLIMPSE framework as a manner to encompass the main challenges agriculture faces on its journey to feed over 9 billion people by 2050 .
\end{abstract}

\section{Keywords}

Food, World, Sustainability, Agriculture, Agribusiness, Farming, Policy 


\section{Introduction}

Thomas Malthus once predicted that population growth would outpace the food supply [1]. While this hasn't happened yet, it's no secret that the world is well on its way to meeting the 9 billion people anticipated to be living by 2050 [2]. While the amount of food that will have to be produced by then may be susceptible to variations-the Food and Agriculture Organization of the United Nations estimates a $60 \%$ increase-it is unquestionable that it will rise [2]. Those of us in the agriculture sector found ourselves asking: Will agribusiness be able to support the necessity for increased food production?

Concomitant to such a questioning scenario, agriculture has drawn peculiar attention from the general public in recent years [3]. Spikes in food prices such as those occurring during the 2007-2008 world food price crisis, food safety concerns such as disease outbreaks, food contaminations, environmental issues, and many others, have all raised awareness among general society [4]. A population, which has shifted away from rural areas and food production techniques, is now concerned with how and where food is produced.

Thanks to the internet, there is a wealth of information readily available to consumers who are now able to monitor production actions across the globe and are more conscious and exigent in decision-making. Alternatively, the outlet of social media is further catapulting information to the fingertips of consumers [5].

This has all come about as a result of social media and the ability of consumers to now voice their opinions and tastes all over the web using a variety of tools and methods [6]. Businesses now know that they must manage social media [5] [7], but what the research here demonstrates is a company or sector can look to determine likemindedness in the virtual world. Through appropriate data analysis, this could be used to future proof businesses in preparation of changes in consumer preferences and trends.

\section{The GLIMPSE Framework}

The use of technology and the internet is ever increasing throughout the world and the agribusiness industry is no different. Still, the sector wrestled with what consumers really want or expect and needed a way to determine trends.

The acronym GLIMPSE was created to help the agribusiness community determine the obstacles it faces [8]. The original research (published in 2012) was conducted to determine the GLIMPSE framework. It was, however, more thoroughly revisited in 2015 in an effort to determine its efficacy over time.

During the second study, the researchers completed a two part analysis. Phase one was a series of interviews with 58 members of the agribusiness community. The group ranged from academic experts to industry leaders and they were asked to discuss the concerns and obstacles facing the agribusiness community.

Taking this collected data, the researchers then conducted a survey of 527 agribusiness professionals. These answers were culled down and found to follow similar con- 
cerns as those posed by the interview phase. Ultimately, it was found that for a second time, the acronym GLIMPSE resembled the primary obstacles the sector faced, but with a few changes (Figure 1 and Figure 2).

\section{The Inclusion of People}

The most obvious change in the revised GLIMPSE is that it now more clearly represents people. This is most obvious as it has been identified as its own category, but several of the other categories have also been altered to show the reflection of people in the form of consumers. For example, "Markets" has now been labeled "Consumer Markets" and "Losses in the food and ingredient supply chain" was adjusted to simply "Losses", to reflect losses at the consumption level, as well as retail and production levels.

Because people have now been identified as an integral part the food chain and thus agriculture itself, it stands to reason that they should be included in the research as well. Given the advancements and spread of the internet and social media in recent years, it was considered relevant to analyze the content of posts published in these vehicles as a proxy of general public opinion. The purpose was to identify and evaluate discussions about the challenges of agribusiness and possibly draw connections to the topics previously categorized. Basically, does public opinion, represented here by social media, reflect the same obstacles and concerns as formerly identified in the interviews with academic experts and industry professionals?

\section{GLIMPSE in Social Media}

\subsection{Crimson Hexagon}

Knowing how extensive the amount of data collected could be, it became the objective to evaluate trends and patterns across the data rather than accurately measuring and classifying each and every post obtained from the sources. Therefore the analysis was mostly done based on frequency of particular words and recurrence of topics automatically classified by an artificial intelligence device known as crimson hexagon. It is a licensed commercial application that stores and searches social media content, and allows users to customize categories and analyze results.

\begin{tabular}{|c|c|c|c|c|c|c|}
\hline G & $L$ & I & $M$ & $P$ & $\mathrm{~S}$ & $E$ \\
\hline Government & $\begin{array}{l}\text { Losses in the food } \\
\text { and ingredient } \\
\text { supply chain }\end{array}$ & Infrastructure & Markets & $\begin{array}{c}\text { Politics } \\
\& \\
\text { Policies }\end{array}$ & $\begin{array}{l}\text { Science \& } \\
\text { Innovation }\end{array}$ & Environment \\
\hline
\end{tabular}

Figure 1. The original GLIMPSE (2012) [8].

\begin{tabular}{ccccccc}
\hline G & L & I & M & P & S & E \\
\hline $\begin{array}{l}\text { Government } \\
\text { \& Policies }\end{array}$ & Losses & $\begin{array}{l}\text { Infrastructure } \\
\text { \& Investments }\end{array}$ & $\begin{array}{c}\text { Markets: } \\
\text { Consumers }\end{array}$ & People & $\begin{array}{l}\text { Science \& Environment } \\
\text { Innovation }\end{array}$ \\
\hline
\end{tabular}

Figure 2. Revised GLIMPSE (2015). 
The sources of social media content analyzed included Twitter, Facebook, blogs, forums and others. The data analyzed had been posted during a three year period, from July $10^{\text {th }}, 2012$ to July $9^{\text {th }}, 2015$. Over one million social media posts were analyzed spanning this timeframe.

\subsection{Methodology}

The engine searched for posts containing main keywords such as "food production" or "agribusiness", with the objective of identifying the industry subject to discussions. This was accompanied by an auxiliary keyword, such as "challenge" or "barrier", with the purpose of identifying themes and topics within discussions related to the industry (Table 1). Posts containing "http" were excluded from the search given the objective of searching for discussions per se, and not referrals to third party websites and/or advertisements.

Upon the manual categorization of smaller samples, the system aggregates the remaining data based on similarities between the content and determined by an intrinsic algorithm. In this study, over 350 posts were manually classified according to criteria (Table 2) that followed the previously determined categories known as GLIMPSE. Any business could utilize this same tool and scour the internet for insight as to where their particular industry is trending and how to prepare for future consumer expectations.

\subsection{Social Media Content Analysis}

The application retrieved 1,395,652 posts meeting the search criteria. The majority of posts were published in blogs and forums. Facebook and Twitter contained the next highest level of posts, and the rest were found in accessory-type social media platforms categorized here as "Other."

Word Frequency

The tool enabled researchers to determine the most frequent words that could be linked to one of the GLIMPSE framework categories (Figure 3). Words such as "water", "government", and "health" can be easily associated to GLIMPSE categories previously described such as Environment, Government \& Policies and Consumer Markets, respectively. This corroborates the comprehensiveness of the framework, but also determines that public perception as determined through social media is represented by these factors as well.

Table 1. Social media content search criteria.

\begin{tabular}{ccc}
\hline Main Keywords & Auxiliary Keywords & Excluded Keywords \\
\hline Food Production or & Issue or Issues or \\
Agribusiness or & Barrier or Barriers or \\
Agricultural Production or & Challenge or Challenges or \\
Agriculture & Opportunity or Opportunities or \\
& Problem or Problems \\
& Future \\
\hline
\end{tabular}


Table 2. Criteria used for each category in the social media analysis (Phase 3).

\begin{tabular}{|c|c|c|}
\hline Category & Description & GLIMPSE \\
\hline $\begin{array}{l}\text { Irrelevant: } \\
\text { Off-Topic }\end{array}$ & $\begin{array}{l}\text { Food recipes } \\
\text { Company Specific info and Advertisement } \\
\text { Weight loss } \\
\text { Non-agriculture related healthcare technologies } \\
\text { Employment offer } \\
\text { Non-agriculture }\end{array}$ & n.a. \\
\hline $\begin{array}{l}\text { Government } \\
\qquad \begin{array}{l}\text { Policies }\end{array}\end{array}$ & $\begin{array}{l}\text { Policies and government decisions } \\
\text { Critics and recall for government regulations } \\
\text { Agricultural policies } \\
\text { International Trade and Economy }\end{array}$ & $\begin{array}{c}\text { Government } \\
\& \\
\text { Policies }\end{array}$ \\
\hline $\begin{array}{l}\text { Investment \& } \\
\text { Infrastructure }\end{array}$ & $\begin{array}{l}\text { Financing of agricultural project } \\
\text { Infrastructure projects }\end{array}$ & $\begin{array}{l}\text { Investment } \\
\qquad \& \\
\text { Infrastructure }\end{array}$ \\
\hline $\begin{array}{l}\text { Resistance to } \\
\text { Advances in } \\
\text { Conventional } \\
\text { Farming }\end{array}$ & $\begin{array}{l}\text { Negative point of views toward: } \\
\text { Biotechnologies being used in traditional farming systems } \\
\text {-GMOs, feed additives, clones, etc. } \\
\text { Production methods such as intensive systems }\end{array}$ & $\begin{array}{l}\text { Consumer } \\
\text { Markets }\end{array}$ \\
\hline $\begin{array}{l}\text { Consumer } \\
\text { Preferences }\end{array}$ & $\begin{array}{l}\text { Health foods/obesity } \\
\text { Eat local/local produced foods } \\
\text { Organic production } \\
\text { "New" eating habits }\end{array}$ & $\begin{array}{l}\text { Consumer } \\
\text { Markets }\end{array}$ \\
\hline $\begin{array}{l}\text { Human } \\
\text { Capital }\end{array}$ & $\begin{array}{l}\text { Educational programs } \\
\text { Women in agriculture } \\
\text { Labor conditions } \\
\text { Population shifts from one area to another } \\
\text { Impact of urbanization on labor } \\
\text { Focus on human capital such as workers or the farmers }\end{array}$ & People \\
\hline $\begin{array}{l}\text { Biosecurity } \\
\text { and Food Safety }\end{array}$ & $\begin{array}{l}\text { Known problems such: } \\
\text { Diseases outbreaks } \\
\text { Pest infestations } \\
\text { Contaminations to food } \\
\text { Exclude uncertainty about new biotechnologies }\end{array}$ & $\begin{array}{l}\text { Science } \\
\quad \& \\
\text { Innovation }\end{array}$ \\
\hline $\begin{array}{l}\text { New } \\
\text { Technology/ } \\
\text { Biotechnology }\end{array}$ & $\begin{array}{l}\text { Information technology } \\
\text { Biotechnology } \\
\text { Other technologies } \\
\text { Excluded health care related biotechnologies }\end{array}$ & $\begin{array}{l}\text { Science } \\
\quad \& \\
\text { Innovation }\end{array}$ \\
\hline $\begin{array}{l}\text { Environmental } \\
\text { Impact \& Natural } \\
\quad \text { Resources }\end{array}$ & $\begin{array}{l}\text { Availability of land } \\
\text { Water scarcity } \\
\text { Other natural resources } \\
\text { Negative impact on the environment } \\
\text { Climate change }\end{array}$ & Environment \\
\hline Others, Losses & $\begin{array}{l}\text { Other challenges not elsewhere classified } \\
\text { Food waste } \\
\text { Starvation and hunger related data }\end{array}$ & Losses, Others \\
\hline
\end{tabular}




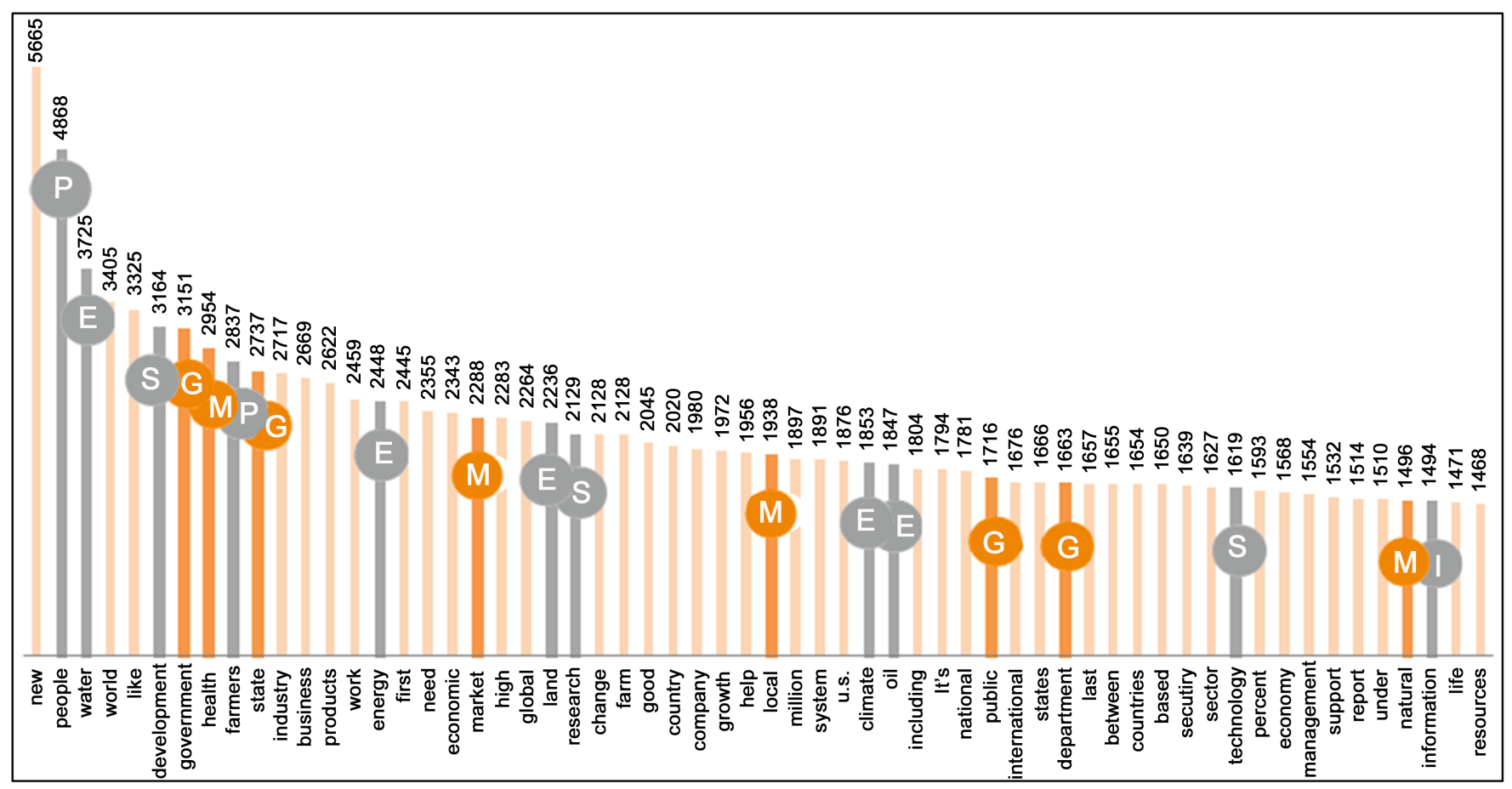

Figure 3. Word frequency among posts [07/10/2012 to 07/09/2015].

\section{Word Clusters}

Another way of analyzing the data is through clusters of words. In this analysis, the relationships of words that frequently appear together in posts are represented by interconnected bubbles. When observing these clusters (Figure 4), researchers were able to easily identify GLIMPSE categories in several of them.

\section{World Clouds}

The major data analysis referred to the frequency of which particular words were stated in posts. Word cloud illustrations were used to identify frequency (larger fonts represented higher frequency). Naturally, the most frequent words of the study were keywords identified within the search criteria. When evaluating results, therefore, keywords have been excluded from the analysis. By observing the remaining data, empirical association can be conducted with the remaining words toward topics representing challenges. Once again, these words may not accurately represent the sole content of the posts but on an aggregated basis, they serve as fair proxies of trends or patterns observed in the data.

When breaking down the data into different periods within the three years of content, word clouds were used to identify slight differences in trends or patterns across time. More words related to Environment and Consumer Markets categories are identified in the word cloud from 2014 to 2015, while relatively more words related to Government \& Policies and Science \& Innovation can be identified in the 2012-2013 word cloud (Figure 5).

When the data is segmented according to the source in which they were posted, some variations in the content can also be noted (Figure 6). Given that most of the overall 


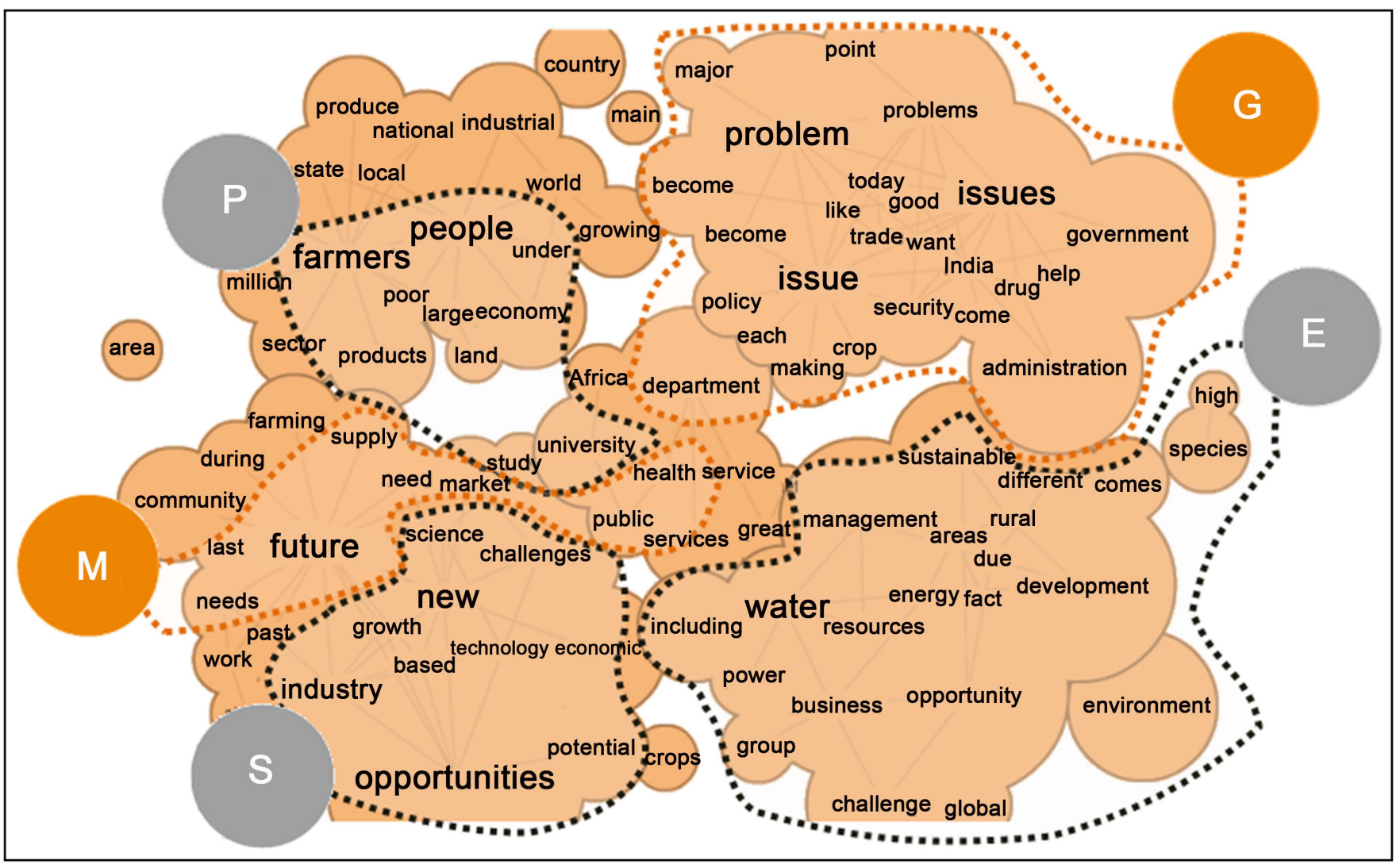

Figure 4. Cluster [07/10/2012 to 07/09/2015; sample of 10,000 posts].

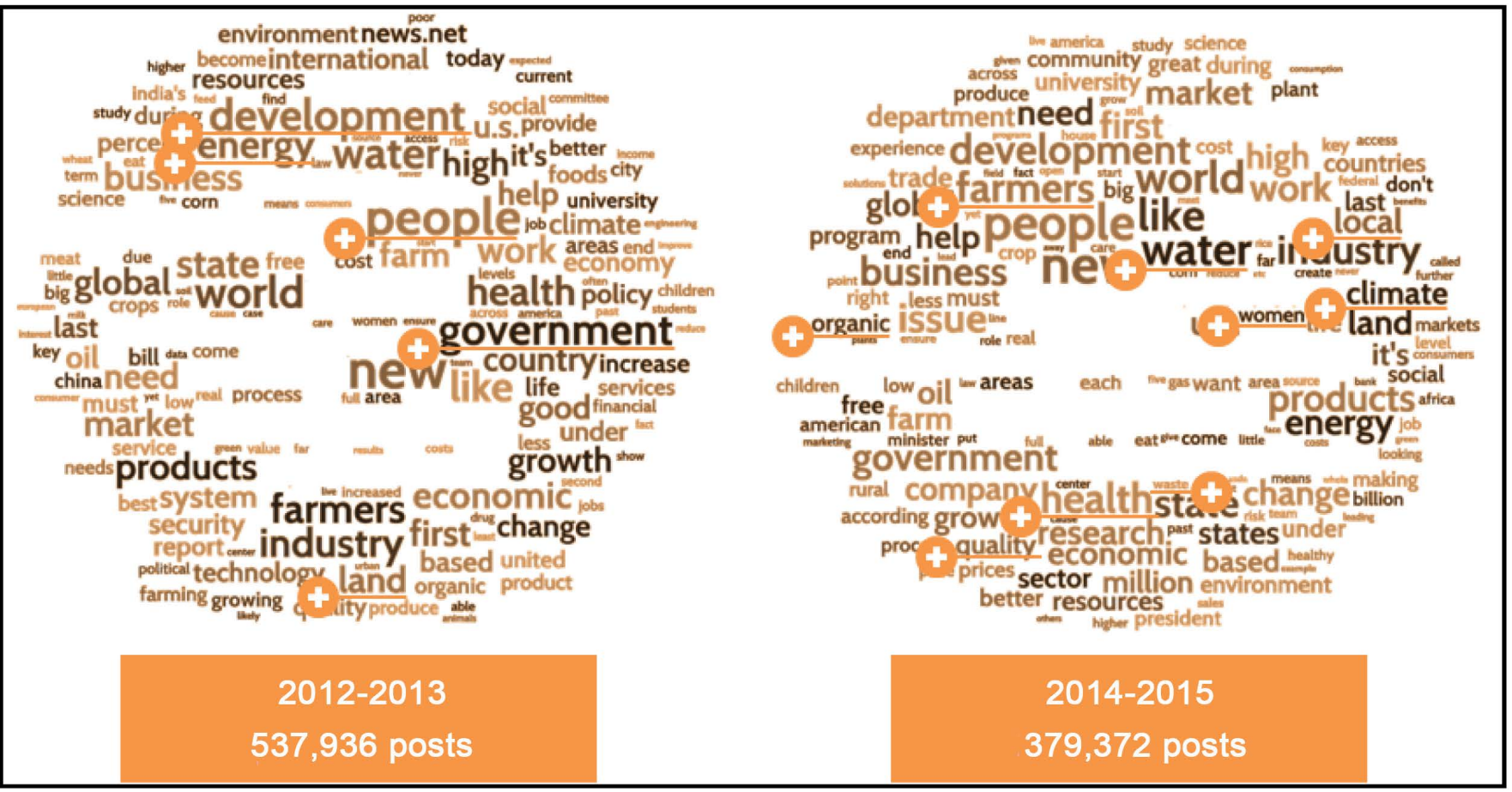

Figure 5. Word cloud without keywords [07/10/2012 to 07/09/2013 and 07/10/2014 to 07/09/2015; sample of 10,000 posts]. 


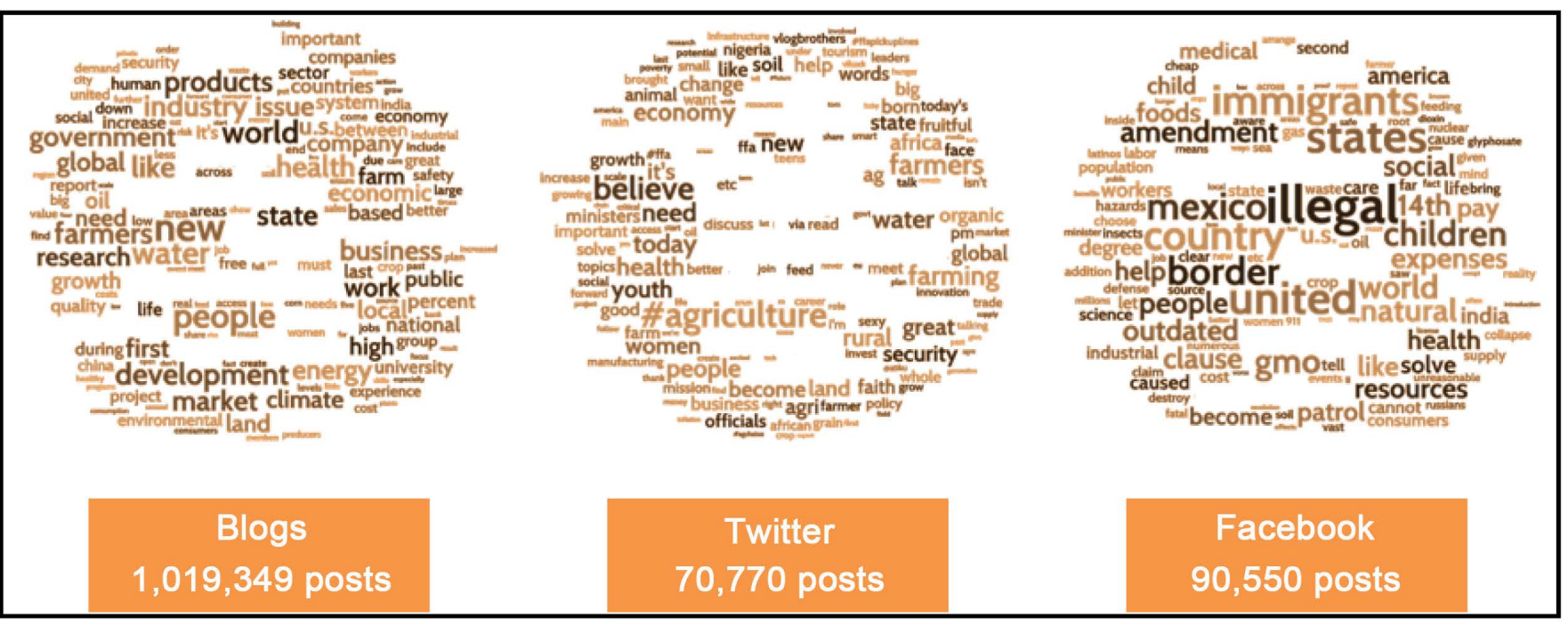

Figure 6. Word cloud without keywords for different content sources [07/10/2012 to 07/09/2015; sample of 10,000 posts each].

data were found in blogs, the word cloud from these sources is more representative of the overall word cloud presented before. In the word clouds of Twitter and Facebook content words related to Government \& Policies and Science \& Innovation are hardly observed, while those related to Consumer Markets and People are predominant. It is important to note that the present analysis does not take into consideration the number of views or engagements (likes, shares, etc.) of posts, but only their content.

By observing the word clouds from each of the categories, correlation between the most frequent words and category theme can be observed. This demonstrates that the application did a fairly satisfactory job categorizing the posts. Nonetheless, some words are recurrently shown in different word clouds. The researchers believe this shows inter-relationship between GLIMPSE categories.

More importantly than the breakdown over the period is how this breakdown changed over the time or how the trend and pattern changed over time. These changes in pattern over time demonstrate changes in how people perceive the issue. Greater amount of posts related to People and Science \& Innovation categories were observed in more recent posts (Figure 7).

\section{Social Media Analysis Conclusions \& Potential}

The researchers of this subject found the social media analysis supported the findings and conclusions obtained in the previous analysis. While this was of course good news, it became increasingly evident just how beneficial this type of analysis could be for any business, government entity or policy maker, NGO, or company looking to gain perspective into the consumer mindset. The content collected from social media was top of mind to consumers; it was unprompted and completely clear of any bias from the part of the researchers.

While this particular research used Crimson Hexagon, there are other platforms available that will analyze across a wide array of information, allowing for easier deci- 


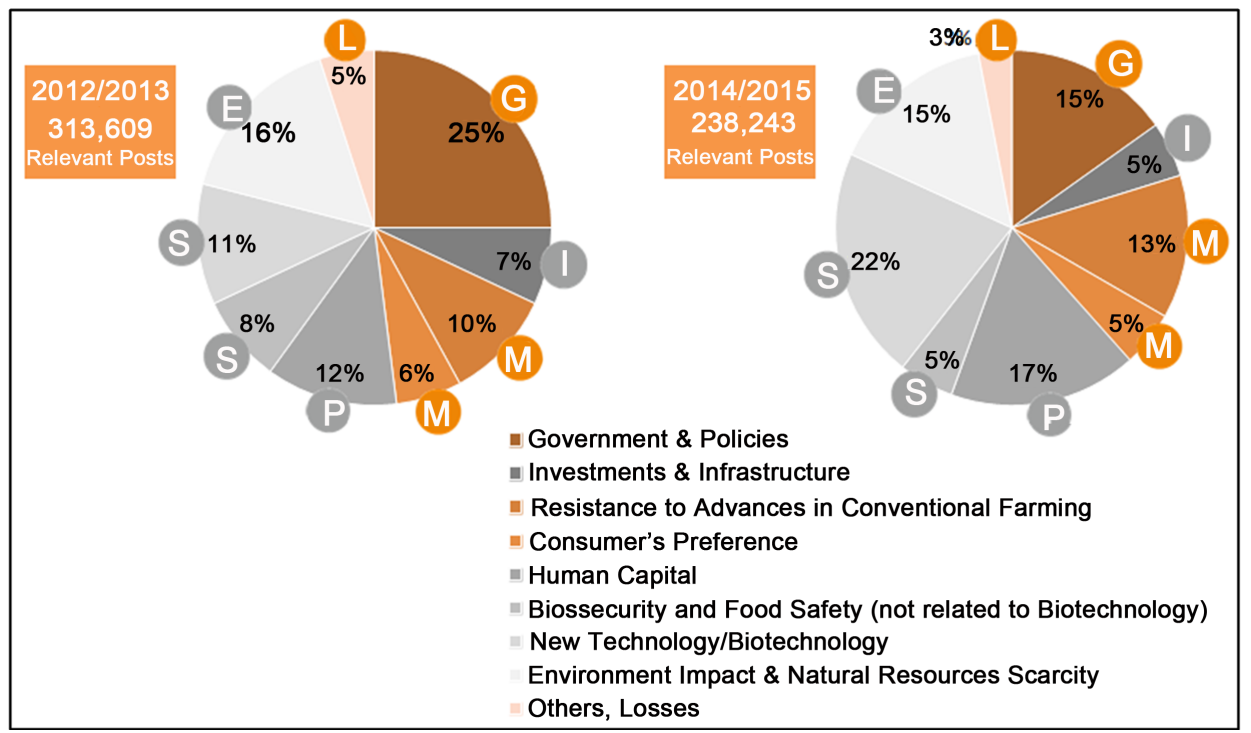

Figure 7. Breakdown (\%) of challenges categories in 2012/13 and 2013/14.

phering of the data. With the onset of big data, there is only to be more gain in evaluating data of this nature. As more and more consumers take their discussions, perceptions, interests, kudos or complaints to the internet, the vast amounts of data available for study are ever increasing. The information is readily available, it is up to the business world to lend a virtual ear toward social media and hear it.

\section{Acknowledgements}

A special thanks to Luiz Roberto Sodre for his dedication of time and energy regarding the social media content analysis.

\section{References}

[1] Malthus, T.R. (1978) An Essay on the Principle of Population. J. Johnson, London.

[2] FAO. How to Feed the World 2050. Food and Agriculture Organization. http://www.fao.org/fileadmin/templates/wsfs/docs/expert_paper/How_to_Feed_the_World in_2050.pdf

[3] Foley, J. (2015) A Five Step Plan to Feed the World. National Geographic. http://www.nationalgeographic.com/foodfeatures/feeding-9-billion/

[4] United Nations. Chapter IV: The Global Food Crisis. The Global Social Crisis. http://www.un.org/esa/socdev/rwss/docs/2011/chapter4.pdf

[5] Lieberman, M. (2014) Visualizing Big Data: Social Network Analysis. https://c.ymcdn.com/sites/www.casro.org/resource/collection/E0F10496-BE87-48E8-8746-5 21D403EE4A2/Paper_-_Michael_Lieberman___Multivariate_Solutions.pdf

[6] Adami, E. (2013) National Centre for Research Methods Working Paper: A Social Semiotic Multimodal Analysis Framework for Website Interactivity. http://eprints.ncrm.ac.uk/3074/4/website_interactivity_Adami.pdf

[7] The Use of Social Media for Research and Analysis: A Feasibility Study. https://www.gov.uk/government/uploads/system/uploads/attachment_data/file/387591/use 
-of-social-media-for-research-and-analysis.pdf

[8] Connolly, A.J. and Phillips-Connolly, K. (2012) Can Agribusiness Feed 3 Billion New People... and Save the Planet? A GLIMPSE into the Future. International Food and Agribusiness Management Review, 15, 139-152.

\section{Submit or recommend next manuscript to SCIRP and we will provide best service} for you:

Accepting pre-submission inquiries through Email, Facebook, LinkedIn, Twitter, etc. A wide selection of journals (inclusive of 9 subjects, more than 200 journals)

Providing 24-hour high-quality service

User-friendly online submission system

Fair and swift peer-review system

Efficient typesetting and proofreading procedure

Display of the result of downloads and visits, as well as the number of cited articles

Maximum dissemination of your research work

Submit your manuscript at: http://papersubmission.scirp.org/

Or contact sn@scirp.org 